\title{
A exploração dos recursos naturais no Porto dos Patos entre os séculos XVI e XIX
}

\section{The exploitation of natural resources in "Porto dos Patos" from the 16thto the 19thcenturies}

Jackson Alexsandro Peres ${ }^{1}$

Resumo: Este artigo investiga como se deu a exploração dos recursos naturais na região da Baixada do Maciambú, a partir do século XVI. Desde então, os navegadores usufruíram dos recursos naturais, especialmente de água, lenha e caça. Além da extração de madeira, ainda conseguiam mandioca e farinha com os indígenas da região. A abordagem segue os pressupostos da História Ambiental e por este motivo, dar-se-á destaque ao estudo e descrição da natureza local bem como a relação do homem com o meio.

Palavras-chave: Porto dos Patos, Baixada do Maciambú, recursos naturais, navegações, viajantes.
Abstract: This article aims at investigating how the exploitation of natural resources has been occurringin the region called "Baixada do Maciambú" since the 16th Century. Since then, the navigators could take advantadge of the natural resources, specially water, wood, and hunting. Besides the wood extraction, they could get "mandioca" and flour from the indians of the region. The theorical approach follows the premisse of the Ambiental History, therefore, for this reason, we attempt to focus on the study and description of the local nature as well as the relationship between the human being and the environment.

Keywords: Porto dos Patos, Baixada do Maciambú, natural resources, navigations, travelers.

\section{Introdução}

\footnotetext{
${ }^{1}$ Professor da Faculdade Municipal de Palhoça (FMP) e acadêmico do curso de Doutorado do Programa de Pós-Graduação em História, (UFSC). Email: peresemail@ hotmail.com
}

Fronteiras: Revista Catarinense de História [on-line], Florianópolis, n.23, p.126-144, 2014. 
Porto dos Patos é o nome que aparece na literatura de viajantes desde o século XVI para identificar a região conhecida hoje como Baixada do Maciambú ${ }^{2}$, no sul do município de Palhoça, Estado de Santa Catarina. Essa região encontra-se defronte à Ilha de Santa Catarina em sua porção meridional. Mesmo com toda a discussão, fontes que levantam a polêmica a respeito do local exato do famoso porto, optamos por confiar nos relatos, mapas e estudos que apontam como o local ao qual nos referimos neste estudo.

A região continental, localizada no extremo sul da Ilha de Santa Catarina, configura-se nos documentos históricos pesquisados como importante local para os navegadores que costeavam o litoral brasileiro desde o século XVI. Naquela altura da viagem e com uma longa jornada pelo caminho para alcançar o Rio da Prata, a região se apresentava como um lugar estratégico para o abastecimento de água, lenha e víveres. Graças às características geográficas, a baía, que é protegida a oeste pela cadeia de montanhas chamada hoje de Serra do Tabuleiro e a leste pela Ilha, apresenta um mar de águas calmas. Além disso, a foz do rio Maciambú também servia como um facilitador para o desembarque dos navegadores, assim como para o embarque da provisão daquilo que era necessário para o abastecimento dos navios e o prosseguimento de suas viagens.

Tendo em vista a recorrência de menções desse local nos relatos de viagem, sobretudo no que se refere à utilização de seus recursos naturais, objetiva-se neste estudo investigar como que a região foi explorada pelos indígenas e colonizadores e também serviu aos navegadores europeus no decorrer de aproximadamente quatro séculos. A análise dessa relação entre homem e meio ambiente se fará a partir da perspectiva da História Ambiental $^{3}$. O recorte temporal expandido resultou do intuito de preencher algumas lacunas sobre a história do local e lançar uma visão holística das

\footnotetext{
${ }^{2}$ É conhecida também como Campos do Maciambú e Campos de Araçatuba. Além disso, pode-se encontrar a grafia Massiambu. Neste artigo utilizaremos a grafia correspondente à fonte citada.

${ }^{3}$ Um dos precursores da História Ambiental, o historiador estadunidense Donald Worster, no artigo intitulado Para fazer história ambiental (1988), coloca que a História Ambiental é parte de um esforço para tornar a História mais inclusiva nas suas narrativas, rejeitando a premissa convencional de que a experiência humana se desenvolveu sem restrições naturais. Além disso, o autor conceitua a "nova" disciplina: "Em termos bem simples, portanto, a história ambiental trata do papel e do lugar da natureza na vida humana." WORSTER, Donald. Para fazer história ambiental. Estudos Históricos, Rio de Janeiro, v. 4, n. 8, p. 201, 1991.
} 
sociedades que ali se desenvolveram e da natureza, além de suas interações. Busca-se, dessa forma, entender não só a relação dos europeus com o meio ambiente, mas também a relação que os indígenas da região (carijós) que tiveram os primeiros contatos com os europeus, tinham com a natureza. Ao abordar a descrição do local, apontando suas principais características geológicas e de fauna e flora, o artigo se fundamenta também interdisciplinarmente, aproximando-se dos campos da geografia, geologia e também da biologia.

Como fontes, fez-se uso de uma bibliografia utilizada ora como apoio, ora como documento, tal a importância e época em que foi escrita. Além disso, o texto terá como base as narrativas deixadas pelos navegadores que fizeram uso dos recursos naturais da Baixada do Maciambú ou de viajantes que a percorreram e deixaram suas impressões sobre o local.

Sobre os primeiros colonizadores europeus e sobre os indígenas da região, a reconstrução da relação destes com o ambiente no período em estudo se dará com o auxílio dos mesmos relatos. O espaço temporal possibilita com isso o uso de diferentes perspectivas, pois os diários de bordo dos navegadores nos séculos XVI ao XVIII eram escritos com objetivos diferentes às narrativas de viajantes que percorreram os caminhos por terra no século XIX. Desse modo, pode-se perceber como o local era percebido pelos diferentes atores em diferentes momentos da história.

\section{Porto dos Patos: localização e características}

Para que se tenha percepção do espaço ao qual se pretende estudar, é importante ter propriedade e entendimento sobre as características locais, bem como sua localização e principais acidentes geográficos. Quando se pretende observar a história sob o ponto de vista ambiental, por exemplo, essa percepção do local não é só necessária, mas sim fundamental, pois é a partir dessa percepção que se entende a dinâmica da relação do homem com o meio.

Worster definiu em seus estudos que, na sua especificidade, a História Ambiental opera em três níveis. Ou seja, há três conjuntos de questões que a disciplina enfrenta, três grupos de perguntas que ela procura elucidar. E por isso, abrange em suas respostas contribuições de outras disciplinas e aplica métodos especiais em suas análises. Essa proposta, que vem sendo aceita e utilizada pelos historiadores ambientais, consiste no entendimento da natureza propriamente dita tal como ela se organizou e funcionou no passado como o primeiro nível de estudos. Nesse nível, é 
imprescindível o auxílio das ciências naturais ${ }^{4}$. Assim, compreender a natureza, e seu papel no passado da vida da sociedade local, será nosso ponto de partida.

Desde que os primeiros navegadores europeus começaram a se aventurar pelo litoral sul brasileiro, se tem discordância quanto à toponímia dada ao local que hoje se denomina Baixada do Maciambú. Porto dos Patos, um dos nomes bastante em voga para designar a região, é motivo de discordância entre os pesquisadores que se debruçam sobre esse período histórico e que procuram, em suas pesquisas, elucidar o cotidiano da Ilha de Santa Catarina no século XVI. Mesmo não sendo o objetivo deste estudo, discorreremos brevemente sobre essa questão.

Lucas Alexandre Boiteux, na obra Santa Catarina no século XVI, não tem dúvidas quanto ao local exato do famoso porto. Em suas pesquisas, o historiador encontrou registros que deixam claro que, o local onde os navegadores ancoravam seus navios para abastecimento, era mesmo, a foz do rio Maciambú. Boiteux ainda chama atenção pelo fato de haverem sempre muitas recorrências aos acidentes geográficos com essa denominação naquele trecho da costa:

Talvez não se encontre em qualquer outra parte do Brasil, talvez mesmo do mundo, em um trecho tão curto do litoral (53 milhas, apenas), como o que se estende da ilha de Santa Catarina à Laguna, tantos acidentes geográficos, com a mesma denominação Patos - na cartografia do século XVI. Vemos: porto, ilha, rio, baía, golfo, laguna, lagoa, terra, índios, capitania, e até... reino, tal a balbúrdia estabelecida pelos navegadores, cartógrafos, desbravadores, em portulanos, roteiros, crônicas, etc., que não sabemos como desfazer cipoal tão emaranhado. Estou convencido, até hoje, que o situo chamado Massiambú ou Massambú e que demora, no continente, à barra sul do porto de Santa Catarina, traz o nome já corrompido pelo perpassar dos tempos, da taba ameríndia em que foram acolhidos os superstites do barco castelhano naufragado ${ }^{5}[\mathrm{sic}]^{6}$.

\footnotetext{
${ }^{4}$ Idem, p. 202.

${ }^{5}$ Sobre os náufragos e sobre o naufrágio a que se refere o autor, comentaremos no próximo item.
} 
Seguindo a mesma linha de pensamento, na obra Porto dos Patos: 1502-1582, João Carlos Mosimann complementa a informação de Boiteux ao afirmar que a região que é atravessada pelo pequeno rio Massiambú e seus dois afluentes, é a única compatível com as indicações existentes. É, ainda segundo o autor, a única região que atenderia a uma característica importante dos guarani: "a de ocupar planícies costeiras de solo arenoso, propícias ao cultivo da mandioca e com a vantagem adicional da proximidade do mar" ${ }^{\text {"7 }}$. Neste ponto, já se percebe a relação de um de nossos sujeitos - os guarani, à época chamados de carijós - com a natureza.

A região conhecida atualmente como Baixada do Maciambú é uma extensa planície, localizada ao sul do Município de Palhoça - SC. A planície foi formada ao longo dos anos pelo recuo do mar, o que pode ser constatado nas fotos aéreas em que se observam claramente os cordões $\operatorname{arenosos}^{8}$ que evidenciam o recuo do mar naquela região:

\footnotetext{
${ }^{6}$ BOITEUX, Lucas. Santa Catarina no século XVI. Florianópolis: Imprensa Oficial, 1950. p. 25-26.

${ }^{7}$ MOSIMANN, João Carlos. Porto dos Patos: 1502-1582. A fantástica e verdadeira história da Ilha de Santa Catarina na era dos descobrimentos. Florianópolis: Edição do Autor, 2004. p.85.

${ }^{8}$ No Brasil, o abaixamento do nível relativo do mar de cerca de 3-4 metros nos últimos 5.700 anos, favoreceu a progradação da linha de costa, originando extensas planícies de cordões litorâneos. In: Cordões litorâneos: “Anéis de crescimento da planície costeira". Disponível em: <http://geologiamarinha.blogspot.com.br/2009/10/cordoes-litoraneos_24.html> Acesso em 22 nov. 2013.
} 
Figura 1 - Baixada do Maciambú e seus cordões arenosos.

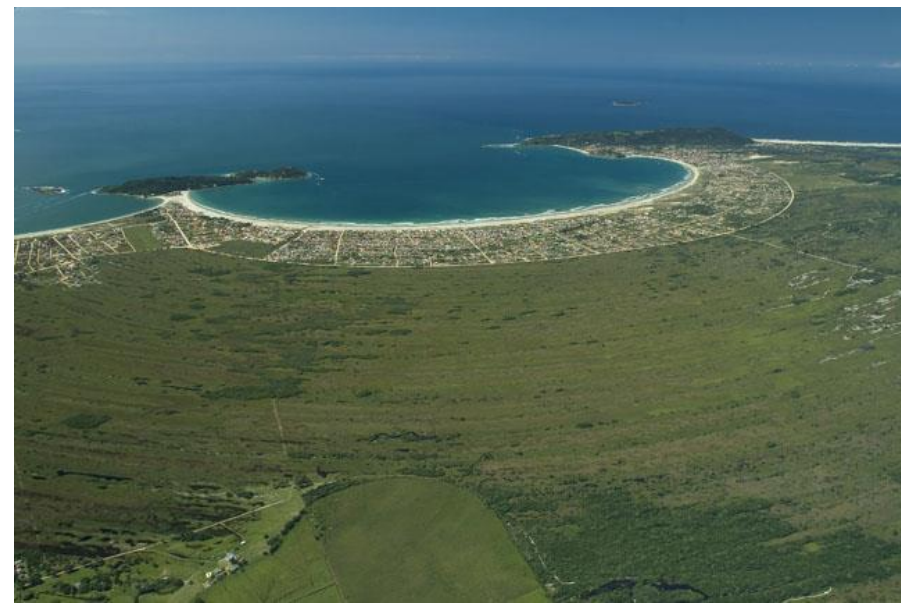

Fonte: Blog do Parque do Tabuleiro 9

Segundo o blog do Parque do Tabuleiro, esse monumento geológico tem importância mundial, pois é caracterizado pelos cordões semicirculares que se formaram no período quaternário (aproximadamente 5.000 anos) e nele ocorrem variadas formações, como lagunas, lagos, dunas, restingas, tômbolos ${ }^{10}$, banhados e praia.

Observando a cartografia do século XVI, podemos perceber que nos últimos quinhentos anos, o local sofreu bastantes modificações. A figura 2, a seguir, é um mapa de 1582 desenhado por Richard Madox e adaptado da obra de Mosimann. Para comparar a região nos idos de $1582 \mathrm{com}$ a formação atual, Mosimann (2004), apresenta o mesmo desenho (figura 3) com a inserção de uma parte hachuriada, que representa como está a região hoje. Podemos perceber que a planície atualmente é maior do que a representada no primeiro mapa (quadrado) e também, é possível observar que Madox, em 1582, identificou o local conhecido hoje como Ponta do Papagaio como sendo duas ilhas: Papagaio Grande e Papagaio Pequeno (círculo). Hoje, a parte identificada como Ilha do Papagaio Grande, no

\footnotetext{
${ }^{9}$ Disponível em: <http://parquedotabuleiro.blogspot.com.br/p/o-parque.html> Acesso em 5 dez. 2013.

10 Tômbolo: é um acidente geográfico no qual uma ilha é unida ao continente por uma estreita trilha de terra (barra) resultante do acúmulo de sedimentos (areia, terra).
} 
mapa de Madox, está ligada ao continente por um tômbolo, como se pode observar na parte esquerda da figura 1 .

Figura 2 - Baixada do Maciambú em 1582 (adaptado).

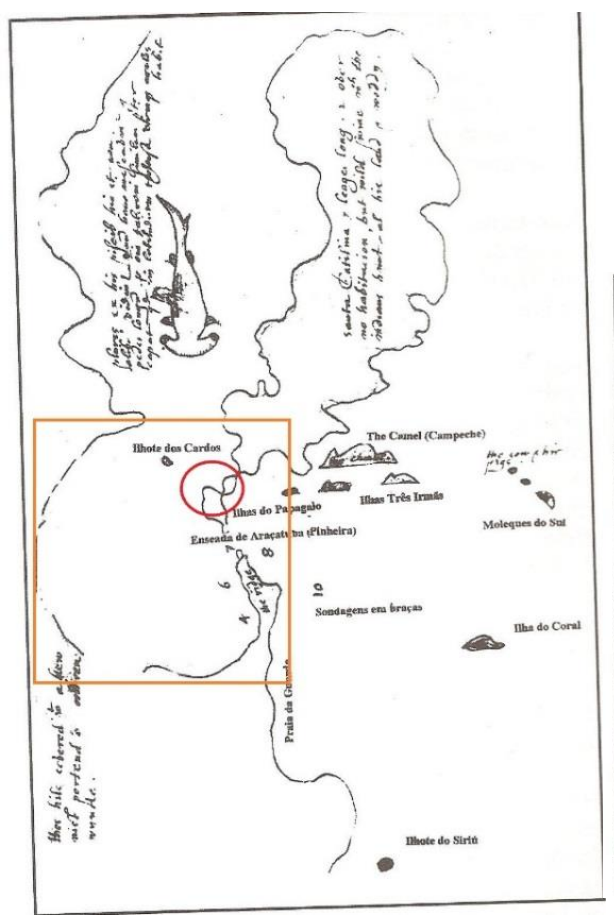

Fonte: MOSIMANN, 2004, p. 52
Figura 3 - Detalhe do Mapa de Richard Madox (1582).

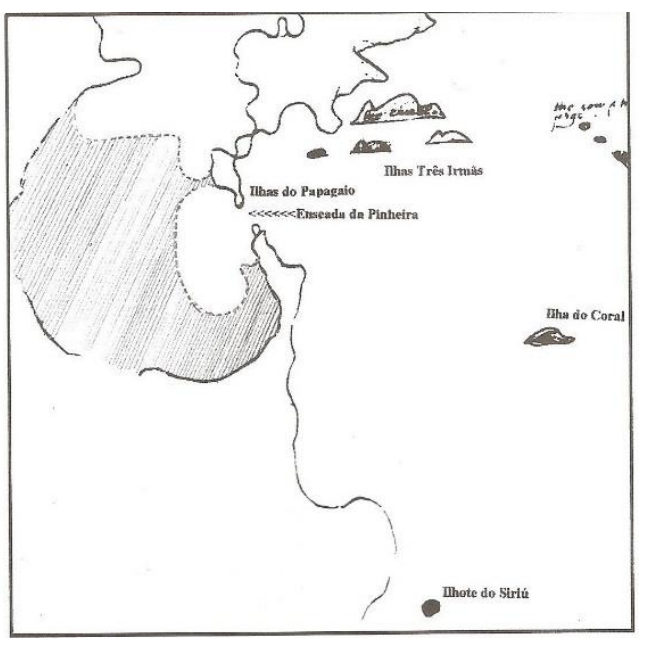

Fonte: MOSIMANN, 2004, p. 155

Acredita-se que a formação do tômbolo que ligou a Ilha do Papagaio Grande ao continente tenha ocorrido no início do século XX. A constatação de que essa formação se deu apenas nesse século é possível por meio de análise das representações cartográficas mais recentes, as quais ainda trazem as ilhas em suas representações. Uma dessas representações é da obra História Militar da Ilha de Santa Catarina, do Marechal Cândido Caldas. A obra, editada em 1992, foi deixada em manuscrito pelo autor que faleceu em 1966. Por esse motivo, supõe-se que a escrita do texto deva ter se dado na década de 1950 ou talvez anterior a isso. Na página 12, o autor 
apresenta um mapa da Ilha de Santa Catarina e regiões próximas. A reprodução do mapa (figura 4) nos permite ver as Ilhas dos Papagaios, localizadas entre a Ponta de Naufragados e o Pontal do Massiambú:

Figura 4 - Mapa da Ilha de Santa Catarina.

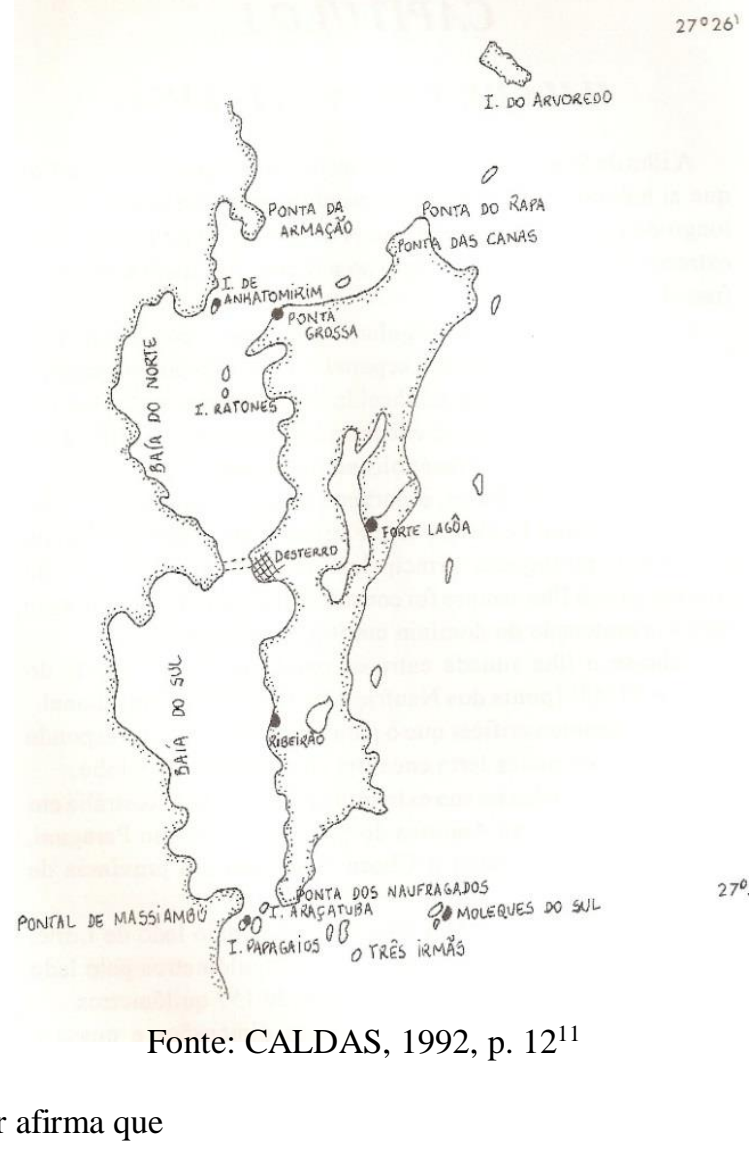

$\mathrm{O}$ autor afirma que

A baía do Sul, também muito alargada no seu interior, tem uma entrada de 3 quilômetros de largura na linha Ponta dos Naufragados, no extremo Sul da Ilha de

11 CALDAS, Candido. História Militar da Ilha de Santa Catarina. Florianópolis: Lunardelli, 1992. p.12. 
Santa Catarina, ao Pontal de Massiambu, no Continente. Apesar dessa largura, a barra do Sul, na prática é apenas a passagem de pouco mais de 300 metros que existe entre a Ponta dos Naufragados e a ilhota de Araçatuba, porquanto ao sul desta até o Pontal de Massiambu, separados por canais de pouco fundo, estão as ilhas de Papagaio Grande e Papagaio Pequeno $^{12}$.

Entender a formação geográfica da região pesquisada e suas características ajuda, neste caso, a compreender não só a ocupação humana naquele local, mas também como essa população se relacionava com o meio. Entendendo as formações naturais, é possível recolher informações preciosas acerca dos recursos disponíveis que essas regiões dispunham à população.

\section{Indígenas, europeus e os recursos naturais no Porto dos Patos}

Existe certa convergência entre os navegadores que estiveram no Porto dos Patos no século XVI e os pesquisadores que se valeram desses registros, em caracterizar os indígenas que viviam na região, os carijós, como um povo receptivo, amigável, e o melhor "gentio" da costa brasileira. Da fatídica viagem do navegador espanhol Juan Díaz de Solís ao Rio da Prata em 1516 ao desenrolar desse episódio, narrado por Mosimann podemos ter ideia da relação estabelecida dos navegadores com os povos indígenas que viviam no Porto dos Patos. Ao desembarcar nas margens do Rio da Prata, atual Uruguai, com oito homens de sua tripulação, Solís e seus companheiros foram cercados e mortos a flechadas. Em seguida, "tomando os mortos nas costas e afastando-se da margem do rio, mas até onde os do navio pudessem vê-los, os índios cortavam-lhes as cabeças, braços e pernas, assavam os corpos inteiros e os comiam"13. Diante daquilo que presenciavam, os demais membros da tripulação se afastaram da costa e prepararam o retorno à Espanha. Ocorre que no regresso,

Ao se aproximarem da Ilha de Santa Catarina, ainda sem nome cristão, uma caravela com cerca de quinze tripulantes, comandada não se sabe por quem,

\footnotetext{
${ }^{12}$ Idem, p. 13.

${ }^{13}$ MOSIMANN, op. cit., p. 17.
} 
desgarrou-se da comitiva e ao tentar adentrar a baía sul, naufragou na barra. [...]. Doze anos depois, o piloto Diego Garcia reencontraria alguns de seus colegas náufragos, em nova viagem ao Prata. Dos quinze tripulantes, onze conseguiram nadar até a praia e obrigados pelas circunstâncias ali permanecer, bem recebidos que foram pelos nativos da região ${ }^{14}$.

Boiteux complementa que foi na ilha ou em alguma enseada da costa fronteira que se refugiaram e se estabeleceram os onze sobreviventes da galé naufragada da expedição de Solís quando retornava do Rio da Prata. Ainda, segundo ele,

Desses homens (caraí-mururú dos silvícolas), temos perfeito conhecimento de três deles: Henrique Montes, Melchor Ramirez e Francisco Pacheco. Seis deles julgo te-los identificado: Aleixo Garcia, Duarte Perez, Francisco Chavez, Francisco Fernandes, Gonçalo da Costa e Fulano Sedeño. Os dois restantes, é provável tivessem morrido, sem deixarem de si a mais vívida memória. $[\mathrm{sic}]^{15}$

Por meio desses relatos, percebemos que os indígenas foram de grande valia para os náufragos da expedição de Juan Díaz de Solís e também para todos os navegadores. Conhecedores da região, os carijós podiam informar com precisão as fontes de água e os melhores lugares para caça.

O local de acesso ao Porto dos Patos (Barra Sul da Ilha de Santa Catarina), era difícil e perigoso, mesmo assim, os navegadores insistiam em aproveitar o local por ser favorável em dois motivos simples: um local protegido dos ventos; e a facilidade dos carijós em estabelecer acordos de troca e auxílio na região ${ }^{16}$.

\footnotetext{
${ }^{14}$ Idem, p. 19.

${ }^{15}$ BOITEUX, op. cit., p. 24.

${ }^{16}$ MORELL, Jean Carlos; LUZ, Luciane da. Os Carijós de Massiambu: o melhor gentio da costa. In: SOUSA, Evandro André de (Org.). A Ilha de Santa Catarina no século das navegações. Indaial: UNIASSELVI/Florianópolis: Insular, 2013. p. 99.
} 
Há registros do início do século XVI que indicam, mesmo sendo a região possessão dos portugueses, que navegadores de diversas nacionalidades usufruíram do Porto dos Patos. Mesmo com toda a dificuldade e perigo que se enfrentava ao alcançá-lo pela Barra Sul da Ilha (ver figura 4), o motivo dessa escolha, tal como apontado por Morell e Luz era, além de se configurar como um lugar privilegiado para a ancoragem, a presença indígena.

Em especial, os carijós da aldeia de Acotia aproveitaram um espaço determinado às suas atividades preferidas: caça e pesca. A foz do Rio Massiambu e a junção de seus afluentes se apresentavam numa planície propícia para a agricultura, o transporte fluvial e atividades de subsistência ${ }^{17}$.

Os perigos da empreitada eram recompensados com a fartura de alimentos. Além da caça, os carijós negociavam os animais que criavam (galinhas e patos) e os produtos que cultivavam como o milho, a batata, feijão, melancia e abóbora. O terreno arenoso e o cultivo de plantas de fácil manejo tornavam a prática agrícola relativamente simples, exigindo dos carijós poucos instrumentos e pouco tempo para o preparo da terra ${ }^{18}$. Além de carne e dos gêneros citados, outros dois alimentos foram essenciais no abastecimento dos navios: a mandioca e os moluscos.

A mandioca era usada para fazer pão, pirão, beiju e uma espécie de aguardente. Para o preparo desses produtos, deixava-se a mandioca de molho durante alguns dias dentro de uma canoa, até amolecer. Em seguida, era prensada em uma peneira para eliminar seu líquido venenoso e deitada a secar. A partir daí é que se conseguiam os seus derivados.

Segundo Coe (2004), o descobrimento da mandioca modificou a pouca estima que se tivesse por este tipo de cultura, pois nenhuma colheita de raízes comestíveis na Europa, como cenoura, rabanetes e nabo, constituía em uma fonte considerável de energia. Para Coe, a mandioca, no início da conquista europeia, foi mais importante que o milho, pois era uma das principais fornecedoras de calorias nas Índias Ocidentais. Ademais, podia ser preparada e guardada por muito tempo, resultando em um produto apropriado para fortalecer os soldados. Além disso, a mandioca,

\footnotetext{
${ }^{17}$ Idem, p. 105.

${ }^{18}$ MOSIMANN, op. cit., p. 36.
} 
Por lo general, esta planta es más consumida em las tierras bajas y húmedas tropicales, lo cual se traduce em que su registro arqueológico sea muy escaso. Pero debe haber sido domesticada em el noreste de Brasil, donde aún crecen numerosas espécies silvestres ${ }^{19}$.

Outro recurso natural aproveitado pelos navegadores foram os frutos do mar. Isso se deve pela geografia do local que facilitava sua extração. Desde os primeiros contatos, os navegadores usufruíram não só de peixes, como também de ostras, mariscos e berbigão, sendo este último até hoje abundante na região da foz do Rio Maciambú.

Amédée François Frézier, engenheiro francês encarregado de construir fortes nas possessões espanholas na América do Sul, aportou em Santa Catarina em 1712. Deixou importante relato, no qual podemos observar a admiração pelas ostras e um elemento novo dentre as possibilidades de caça, os gados selvagens de "Arazatiba"20.

Ao romper do dia avançamos ainda uma meia légua para verificar se não havia algum navio fundeado em Arazatiba, o que não foi visto. Um dos nossos oficiais que aí havia estado com M. Chabert, chamou-nos atenção para uma ponta de terra baixa onde se encontravam manadas de bois selvagens, [...]. A leste da ilhota Fleury existe uma enseada onde se encontra muito boa água e pequenas ostras verdes de um sabor delicioso $^{21}$.

No mesmo relato, Frézier descreve como a pesca é abundante nas inúmeras enseadas, tanto da Ilha, quanto da terra firme e cita algumas espécies de peixes que ele e seus homens pescaram como sargos, carapaus, "machorans", roncadores, peixes-galo e peixes-rei. Além disso, revela que a caça na região é tão abundante quanto à pesca e que os pássaros mais comuns para este fim são os papagaios. Porém, "a caça ordinária aos habitantes é o macaco, de que comumente se alimentam: mas a melhor de

\footnotetext{
${ }^{19} \mathrm{COE}$, Sophie D. Los productos Del Nuevo Mundo. In: Las primeras cocinas de América. México: FCE, 2004. p. 37.

${ }^{20}$ Grafia do século XVIII.

${ }^{21}$ HARO, Martins Afonso Palma. Ilha de Santa Catarina: relato de viajantes estrangeiros nos séculos XVIII e XIX. $4^{a}$ Edição. Florianópolis: Editora da UFSC, Editora Lunardeli, 1996, p. 22.
} 
todas para os navios em estadia é a dos bois, dos quais há uma grande quantidade em terra firme, perto de Arazatiba, como já disse"22.

George Shevolke, outro navegador que esteve na Ilha de Santa Catarina e na costa fronteira em 1719, traz também em seus relatos, os aspectos relacionados aos recursos naturais que a Ilha e o continente ofereciam à época. Diverge de Frézier no que diz respeito à caça, afirmando que "existe muito pouca, embora as matas estejam cheias de papagaios" 23 . Entretanto, converge com Frézier ao relatara abundância de peixes de diversas espécies e também a facilidade de pescá-los, além de afirmar que os crustáceos também fizeram parte da dieta dos navegadores.

Lá cada pedra e até mesmo as raízes das árvores à beira da água, abrigam uma deliciosa espécie de ostras verdes de pequeno tamanho. Da mesma forma, entre pedras junto às praias, pode-se encontrar o que comumente se chama de mariscos; em sua forma exterior eles muito se assemelham aos ouriços do cais [...] em minha opinião, supera em sabor a toda espécie de crustáceo que jamais provei ${ }^{24}$.

A presença de ostras nas raízes de árvores dá-se pelo fato dessas raízes estarem em contato com água salgada. Esse tipo de ecossistema, presente em áreas pantanosas (mangues) é bastante comum em algumas regiões da Ilha de Santa Catarina e também na foz Rio Maciambú, no local que estamos chamando de Porto dos Patos ${ }^{25}$.

Além dos peixes e dos crustáceos, Shevolke também dá notícias de gados na parte do continente. Escreve ele: "Nas savanas de Arezitiba, no continente, bem em frente à parte extrema sul da Ilha de Santa Catarina, eles tem gado preto em grande número, algumas das quais nos foram fornecidas e que compramos a preço razoável" 26 . A presença de gado no continente, na planície de Araçatuba (Baixada do Maciambú) é bastante antiga, como podemos perceber pelos relatos supracitados do início do século XVIII. Essa presença pode ser entendida tanto pela questão natural (por serem

\footnotetext{
${ }^{22}$ Idem, p. 27.

${ }^{23}$ Idem, p. 46.

${ }^{24}$ Idem, p. 46.

${ }^{25}$ As ostras, citadas nos relatos de Frézier e Shevolke, são ainda hoje encontradas em áreas tanto da Baía Sul quanto da Baía Norte por causa do mar calmo, já que não se desenvolvem em costões de praias de mar aberto.

${ }^{26}$ HARO, op. cit., p. 47.
} 
áreas de pouco relevo, com presença de capim e de água) como pela questão cultural (criação de gado em campos abertos, sem cuidados especiais).

Quando de sua passagem pela Ilha de Santa Catarina, em 1798, o inglês James George Semple Lisle também se ocupou em registrar suas impressões sobre o local. Além da natureza e dos produtos que conseguia na Ilha, Lisle descreveu os costumes dos habitantes que residiam nela. Em uma passagem, o viajante caracteriza os habitantes como preguiçosos e chama atenção para a procedência do gado naquela região:

A Ilha de Santa Catarina é notavelmente fértil e poderia, com pouco esforço, tornar-se um local muito produtivo; mas tão grande é a preguiça de seus habitantes, que muito pouco ou nada é feito por eles, sendo que o próprio gado para consumo deve ser trazido de Rio Grande ${ }^{27}$.

Poucos anos depois, o russo Georg Heinrich Von Langsdorff, despendeu várias páginas de diários para descrever tanto a Ilha quanto o litoral fronteiriço. O médico esteve na província em 1803. Dedicou-se por conta própria à História Natural e isso fez com que se ocupasse em coletar e catalogar muitas espécies de plantas e animais. Seu olhar científico permitiu-lhe descrever a paisagem, o clima e demais aspectos do lugar visitado com minúcias. Permaneceu em Santa Catarina de 20 de dezembro de 1803 até fevereiro de 1804. Percorreu não só a Ilha como o continente próximo, e não se pode dizer com exatidão se ele esteve na região em estudo, já que não deixou registros que pudessem ser identificados como sendo aquelas terras. No entanto, o médico russo também traz uma análise sobre o gado criado na parte continental, o qual se está destacando por ser um diferencial dentre os recursos explorados. Escreve Langsdorff:

A maior parte da província de Santa Catarina é, no sentido mais próprio, uma terra costeira, habitável apenas de 6 a 8 milhas alemãs para o interior, isto é, em direção a oeste. Já a uma distância de duas horas ou de uma milha alemã, só se encontram choupanas dispersas, muito distante uma das outras e pertencentes a pessoas das mais pobres, cuja subsistência está na criação de gado. Eles possuem tropas cercadas em

${ }^{27}$ Idem, p. 126. 
grandes pastagens e sem cuidado especiais passam o ano inteiro em liberdade, multiplicando-se, sem que o proprietário saiba exatamente o número de animais de sua tropa. Estes bois selvagens, ou melhor, semi selvagens, custam, no interior, apenas 1 a 2 táleres espanhóis e são levados em tropas para a costa e para a ilha, na vila de Nossa Senhora do Desterro. [...]. O transporte de tal tropa está ligado a grandes dificuldades e por isto, o preço de um boi encarece ao dobro, pelo menos, até que se alcance a Ilha de Santa Catarina $^{28}$.

Percebe-se, pelas descrições acima, que o gado era mesmo criado no continente de uma maneira bastante rudimentar, o que talvez tenha dado aos navegadores a ideia de um animal selvagem. A presença de gado nas savanas de Arazatiba (Araçatuba), no início do século XVIII pode ser explicada devido ao desenvolvimento da pecuária na Província do Rio Grande. Na obra Terras Comunais na Ilha de Santa Catarina, Nazareno José de Campos coloca que em Santa Catarina desenvolveu-se, entre o planalto e o litoral, diferentes caminhos por onde passavam as tropas. Nesses caminhos surgiram campos de pouso de gado, para descanso e engorda. O gado que vinha pelo sul da Província encontrava extensas áreas para este fim. Uma delas no Campo D'uma, no atual município de Garopaba e nos Campos de Araçatuba ${ }^{29}$. Esta última seria a "savana de Arazetiba" de Frézier e Schevolke.

Em 1820, é a vez de Auguste de Saint-Hilaire, um botânico e naturalista francês, dar notícias da relação dos habitantes da Ilha de Santa Catarina com a criação de bovinos. Suas observações esclarecem a relação entre o gado do Rio Grande e Desterro. Mesmo sem mencionar os gados dos campos de Araçatuba, elucida as conclusões de Campos, sobre os caminhos do gado no litoral.

Como as terras da Ilha de Santa Catarina estejam muito repartidas e os pastos tenham pouca extensão, o gado ali é pouco numeroso e caro, em relação aos preços correntes no planalto, em Curitiba e nos Campos Gerais. Os bois abatidos em Desterro vêm da Província

\footnotetext{
${ }^{28}$ Idem, p. 164.

${ }^{29}$ CAMPOS, Nazareno José de. Terras comunais e pequena produção açoriana na Ilha de Santa Catarina. Florianópolis: FCC/Ed. da UFSC, 1991. p. 86.
} 
do Rio Grande, sendo trazidos por terra, seguindo o litora $^{30}$.

Pelas descrições e impressões, conclui-se que a presença de gado no Porto dos Patos, descrito e explorado pelos navegadores e pela população local, resultou do deslocamento das tropas que saiam do Rio Grande em direção ao norte pelo caminho do litoral. Alguns certamente se desgarravam e permaneciam naquele que era um local de pastagem natural, multiplicando-se.

Apesar da importância do porto nos séculos XVI, XVII e XVIII, a presença indígena no local, as plantações de milho, algodão $\mathrm{e}$ principalmente mandioca, e a presença do gado, esses fatores não foram capazes de no século XIX, proporcionar aumento significativo de presença humana na região. Ressalta-se também que os relatos dos séculos XVIII e XIX não trazem informações sobre a aldeia indígena, apontada pelos navegadores que aportavam no Porto dos Patos durante os séculos como uma aliada.

Essa impressão, de que a região, com o passar do tempo, foi perdendo sua importância, muito por conta do desenvolvimento do porto e da Vila de Nossa Senhora do Desterro, na Ilha de Santa Catarina, se confirma através dos relatos de outro viajante, Robert Avé-Lallemant. O médico e explorador alemão esteve na Província de Santa Catarina no ano de 1858 e deixou suas impressões na obra Viagem pelo Sul do Brasil em 1858. Quando deixa a Ilha de Santa Catarina em direção ao sul, descreve assim o trecho hoje conhecido como Morro dos Cavalos, em Palhoça:

Depois o caminho se elevou escarpadamente; ainda uma vez tive pleno olhar retrospectivo da Ilha de Santa Catarina e segui pelo solitário caminho da serra, em cujas árvores e blocos de granito, numerosas orquídeas haviam aberto as suas flores. De um longínquo desfiladeiro, cujos picos e contrafortes formam graciosas cadeias e belas perspectivas, desce, no próximo vale, o Maçambu. Só é navegável uma milha rio acima, mas é bastante profundo. Os cavalos atravessaram-no nadando; uma pequena canoa transportou os viajantes, tão pequena que, além do

\footnotetext{
${ }^{30}$ SAINT-HILAIRE, August. Viagem a Curitiba e Santa Catarina. Tradução Regina Régis Junqueira. Belo Horizonte: Ed. Itatiaia, 1978. p. 176.
} 
remador, só comportava dois homens, obrigados a sentar-se no fundo para que não virasse o tronco de árvore escavado ${ }^{31}$.

Mas adiante, ao descrever a paisagem da Baixada do Maciambú (Porto dos Patos), o viajante em momento algum se refere aos gados, isso porque se mostra mais preocupado com a descrição da flora. Também não faz referência aos indígenas, que já há tempos tinham sumido dos relatos dos navegadores.

Recebeu-nos um vale pantanoso e cheio de areia. Frequentemente o solo pantanoso é coberto de longas gramíneas e estende-se, como um mar de relvas, até a montanha. Em geral o solo é pouco elevado e oferece, sobre suas colinas de areia, vegetação bastante rica, invulgar e atraente, em que representam o papel principal as bromeliáceas, orquídeas e melostomáceas em flor, desde grandes moitas até pequeninas plantas herbáceas ${ }^{32}$.

Curiosamente, a região, que por sua posição e por seus recursos naturais foi de grande importância aos navegadores, podendo se apresentar como uma região promissora para ocupação foi sendo esquecida ao longo do século XIX. Robert Ave-Lallemant assinala essa questão, dando-nos a impressão de uma região onde a ação antrópica foi quase inexistente:

E todavia apresenta a região um ar de profundo ermo e abandono. Em parte alguma se encontra uma casa, mas apenas aqui e ali, vestígios de plantações; o solo, obstinado, recusa compensar qualquer esforço. Mesmo onde se comprime em floresta, o matagal é raquítico e coberto de parasitas de todas as espécies ${ }^{33}$.

\section{Considerações finais}

31 AVÉ-LALLEMANT, Robert. Viagem pelo sul do Brasil no ano de 1858. Tradução de Teodoro Cabral. Rio de Janeiro: Instituto Nacional do Livro, 1953. p. 30.

${ }^{32}$ Idem, p. 30.

${ }^{33}$ Idem, p. 31. 
Neste artigo buscamos elucidar como que a região conhecida na literatura de viagem do século XVI como Porto dos Patos teve papel fundamental no processo de reconhecimento e de colonização das regiões pertencentes a Portugal e Espanha. Isso porque a topografia da região permitiu que o local fosse utilizado como um porto natural, facilitando a ancoragem dos navios que estavam em curso para a região da foz do Rio da Prata. As águas calmas da Baía Sul, protegidas pela Ilha de Santa Catarina e o continente, a foz do Rio Maciambú, que facilitava a descida em terra dos navegadores, além da fartura em recursos naturais necessários ao prosseguimento da viagem, deram certo prestígio ao lugar.

Lenhas, água, plantas e animais, além de peixes e crustáceos, foram os principais recursos naturais explorados pelos navegadores de diversas nacionalidades que estiveram no litoral sul do Brasil entre os séculos XVI e XIX. A aldeia indígena, existente no local, identificada como sendo os seus moradores, os melhores indígenas do litoral brasileiro, foi um facilitador. Além de contarem com os indígenas na identificação dos melhores locais para se conseguir água e alimentos em abundância, os exploradores contavam também com os produtos que eram cultivados pelos índios, sobretudo a mandioca.

A caça obviamente era uma prática comum para se conseguir alimento. Percebemos nas fontes que principalmente as aves, como os papagaios, eram as mais apreciadas. Não comum, no entanto, era ter o gado como uma dessas opções de caça. Registrado naquela região desde o início do século XVIII, esse gado selvagem, que resulta dos animais que em deslocamento do Rio Grande do Sul para o norte, desgarravam-se e permaneciam na Baixada do Maciambú, foi de grande valia para os navegadores. Mesmo não se tendo notícias desses animais nas fontes pesquisadas, durante o século XIX, acreditamos que a criação do gado solto, na região, foi praticada ininterruptamente até os dias atuais. Hoje, uma área da região da Baixada do Maciambú serve aos moradores como área comum para criação de gado, mesmo essa área estando dentro do Parque Estadual da Serra do Tabuleiro, criado em 1975. A história da presença de gado na região da Baixada do Maciambú se configura como uma proposta para um trabalho futuro, com pesquisas em outras fontes, mas que para fins deste artigo, se apresenta como inviável.

Por fim, percebemos que a região, mesmo com toda a importância exercida nos primeiros séculos que se seguiram à chegada dos europeus, não teve um crescimento demográfico expressivo. Hoje há uma população 
indígena Guarani vivendo na região, disputando espaço com comunidades não-índias. Essa população local, assim como os navegadores dos séculos XVI, XVII, XVIII e XIX, se utiliza dos recursos naturais, principalmente da pesca e da agricultura de subsistência, além da criação de gado já citada. Esse fator tornou possível a manutenção dos aspectos naturais da região, sendo que foi somente a partir da década de 1970 que algumas áreas desse litoral passaram a sofrer com a especulação imobiliária e a descaracterização de áreas próximas do mar. Mesmo assim, a população não-índia que vive na região retira seu sustento principalmente do mar, consumindo peixes e crustáceos. Hoje, essa população também se ocupa com a maricultura e com a exploração do turismo. 